\title{
On the Cultural Peculiarities of Proverbs and Their Classification
}

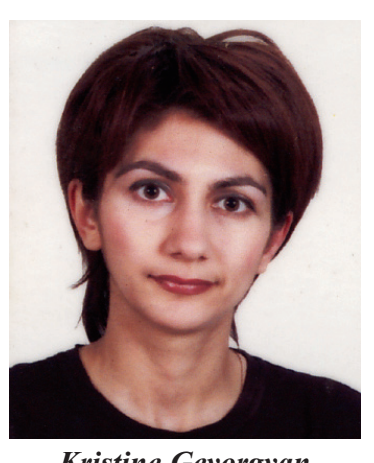

Kristine Gevorgyan

\begin{abstract}
Wery society has a verbal cultural heritage, "an inventory of Lore" (in Lowen's terms), which has passed from generation to generation, and proverbs are a constituent part of the "inventory". Dating back to ancient times they are still actively used in everyday speech, in media, in literature, and political speeches. However proverbs form one of the most intricate layers of the vocabulary and are so deep and many-faced that they still require further investigation on various levels. The present article focuses on the formal view, which is characterized by attempts to describe the linguistic and logico-semantic properties of proverbs (Honeck 1997:11), as well as on the cultural approach.
\end{abstract}

The earliest collections of proverbs can be traced as far back as ancient Egypt, about 2500 B.C. Aristotle was the first person who was more systematically engaged in the collection and classification of proverbs (384-322 B.C.). In the middle ages proverbs were widely used in Christian texts, sermons, homilies, which consequently made them popular all over Europe. Only in the $15-16^{\text {th }}$ centuries proverbs were first collected and published but at that period, being considered part of folk culture, they were studied as relics of folk wisdom and culture. The Elizabethan era made proverbs more popular since they were used and quoted by famous playwrights of the period (Lyly, Jonson, Shakespeare, etc.). In the 19-20th centuries proverbs appeared in the center of interest of dictionary compilers and scholars in different countries.

Paremiology and phraseology are the two main spheres which deal with proverb studies. Paremiology (from Greek paremia $=$ proverb) collects, classifies, and investigates proverbs. As W. Mieder states, "Paremiologists usually look at proverbs from more inclusive point of view as they draw on such fields as anthropology, art, communication, folklore, history, literature, philology, psychology, religion, and sociology" (Mieder 2004:13).

So what is a proverb? What are those main features which characterize the proverb? Almost everybody knows the word "proverb", but not everybody can explain what it is and where it comes from. Many scholarly articles ask the same question. Paremiographer Archer Taylor states, "The definition of a proverb is too difficult to repay the undertaking. An incommunicable quality tells us this sentence is proverbial and that one is not. Hence no definition will enable us to identify positively a sentence as proverbial" (cited by Dundes 1994:44). Speaking about the concept of proverb 
R.Honeck mentions, "It is a complex, intriguing, and important verbal entity" (Honeck 1997: vii). All this has made the phenomenon of proverb a subject of heated discussions.

Let us look at some proverb definitions and try to disclose its characteristic features. While discussing the formal view on proverbs Honeck suggests several definitions, some of which are worth considering here. In the $15^{\text {th }}$ century Michael Apostolius of Byzantium gave the following definition of the proverb: "A proverb is a statement which conceals the clear in the unclear, or which through concrete images indicates intellectual concepts, or which makes clear in furtive fashion"(cited by Whiting 1932:287).

The Encyclopedia Britannica defines the proverb as "a succinct and pithy saying that is in general use and expresses commonly held ideas and beliefs" (http://www.britannica.com/). The Columbia Encyclopedia defines it as "a short statement of wisdom or advice that passes into general use" (http://www.bartleby.com/.). According to The Russian Dictionary of Proverbs and Sayings, "Proverbs are brief oral sayings on different themes... Neat aphorisms which can expressively and explicitly characterize anything without tedious and complex explanations... They enclose national appreciation of life... Behind each proverb stands the authority of generations which created them" (Slovar russkikh poslovits i pogovorok 1966:3).

The Dictionary of America's Popular Proverbs and Sayings gives the following definition: "Proverbs are collective wisdom of all nations, of all ages, of all times. A proverb typically expresses a commonplace thought in a succinct, often metaphorical way" ( The Dictionary of America's Popular Proverbs and Sayings, 2000:vii).

The Longman Dictionary of English Language and Culture states that the proverb is "a short well-known, supposedly wise, saying usually in a simple language" (The Longman Dictionary of English Language and Culture, 1998:1075).

According to The Oxford Advanced Learner's Dictionary - "Proverb ... a wellknown phrase or sentence that gives advice or says something that is generally true" (The Oxford Advanced Learner's Dictionary 2006:1169).

W. Mieder suggests the following definition of the proverb: "Proverbs [are] concise traditional statements of apparent truths with currency among the folk. More elaborately stated, proverbs are short, generally known sentence of folk which contains wisdom, truth, morals, and traditional views in a metaphorical, fixed and memorizable form, which is handed down from generation to generation" (Mieder 2004:4).

Thus, it can be seen that various sources give different definitions to the proverb, although in the majority of cases they reveal identical features. Their analysis brings out certain common characteristics: "short", "simple", "well-known", having "metaphorical meaning", "true", showing "experience", expressing "collective/national wisdom". If we generalize these features, it becomes obvious that proverbs are based on national wisdom and experience, are short, true and simple.

National wisdom reflects how we perceive the world through the prism of our national outlook and identity. It is entwisted with culture issues. Theories by Von Humboldt, Sapir, Whorf, Boas played an important role in proverb studies and broadened their frames, drawing the analysis of the proverb into the sphere of language- 
culture interrelations. Today proverbs are viewed both in the system of language and in the context of culture. In connection with the above-mentioned problem, A.Wierzbicka quotes von Humboldt, bringing forward the following idea: "[E]ach language ...contains a characteristic worldview. As individual sound mediates between object and person, so the whole of language mediates between human beings and the internal and external nature that affects them (Wierzbicka 1992:3)". The cultural view, proposed by Honeck, concentrates on the use of proverbs in sociocultural contexts: “...proverbs are cultural linguistic products, created and used in social situations for social purposes...[they] entail the codification of important lessons in the culture" (Honeck 1997:31).

The definitions mentioned above do suggest that proverbs have been created by the nation. Thus, national identity and the issue of cultural variety are significant since proverbs are viewed as carriers of national identity. Surely we cannot state that the whole stock of proverbs in any language has been created only by the nation. The origin of the majority of proverbs is unknown, and often the nation is considered their creator, e.g. As Maine goes, so goes the nation; Вот тебе, бабушка, и Юрьев день; An Englishman's home is his castle. Literary works can also serve as a source of proverbs which penetrate into everyday speech: He who lives by the sword dies by the sword; Aim at heaven and you will get earth thrown in. Aim at earth and you get neither; All that glisters is not gold and enter into everyday speech. In the majority of Indo-European languages, e.g. Armenian, Russian, English, German a certain amount of proverbs have roots in Latin, Greek and other languages. Nevertheless, whatever the source language of the proverb, as time passes it can acquire the specific national colouring peculiar to the given language. Mieder mentions four main sources of European proverb distribution: 1.Greek and Roman antiquity; 2. the Bible; 3. Medieval Latin; 4. Through Mass media from US to Europe (Mieder 2004:10-13). To make it more vivid let me introduce some examples of proverbs from English, Russian and Armenian, which express the same idea, though the wording is different, e.g. An apple a day keeps a doctor away.-Лук от семи недуг. Appearances are deceptive.- Личиком гладок, да делами гадок. As the cock crows so

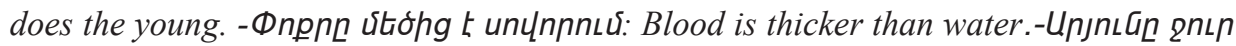
sh пunGiш; A bully is always a coward.- Шкодлив как кошка, а труслив как заяи.unumpunn uhzen th yufulnen t:

And since proverbs, as stated above, "entail the codification of important lessons in the culture", they reveal different attitudes towards various notions, concepts, and objects, e.g. Every man has a fool in his sleeve. 9oh ns hnuha Guunh, ns tL upluha: Береги платье снову, а честь с молоду. Adversity makes strange bedfellows. Пuцha vian t, qhan duln t: Наше дело телячье. Example is better than precept. Пословица вовек не сломится. Funh uhnunn qnhwnhg цшц L: Envy shots at others and wounds herself. Работа дураков любит. Свято место пусто не бывает. ¿nьар гша ршр sh $4 \delta h$.

The other field of linguistics engaged with proverb studies is lexicology, phraseology in particular. Phraseology studies proverbs and sayings from the structural point of view as well as touches upon classification issues. They were included into the sphere of phraseology in the middle of the $20^{\text {th }}$ century, although were not accepted 
unanimously. Mieder and Dundes in the preface to their book mention, "Phraseology is more developed in Eastern and Western Europe and their linguistic orientation is starting to take hold in the United States too" (Mieder Dundes 1994:xi). In fact, Ch.Bally's theory of types of word combinations, found its later development in the works of Vinogradov, Polivanov, Amosova, Kunin, who "transformed" word combinations into "phraseological units", singling out their types and features. Certain types and concepts are still under consideration, and there are different approaches to the question of classification. One of such issues is the concept of "idiom" or "idiomatic expression" since American linguistics often includes word-combinations as well as proverbs and sayings into idioms, idiomatic expressions, whereas Russian linguistics views idiom as a type of word combination whose meaning is difficult to deduce from its components due to its metaphoricity.

Kunin was among those who always viewed proverbs as part of phraseology (1970, 1996). In his classification of phraseologisms he singles out four main classes: Nominative, Nominative-communicative, Interjectional, and Communicative. Proverbs and sayings form a separate group and are called Communicative phraseological units. According to Kunin, " Proverbs are usually understood as aphoristically compressed and rhythmically organized sayings with instructive sense" (Kunin 1996:339). In his description of communicative phraseological units Kunin stresses that they are wholly predicative sentences. The same idea is emphasized in Mieder's definition, however in western scholarly tradition proverbs are referred to as sayings. Kunin singles out sayings as a separate type, bringing forward their characteristic feature and calling them "phrases of non-proverbial type", whereas in the majority of European proverb dictionaries, sayings are viewed and studied as proverbs.

As far as proverb taxonomy is concerned, there are different classifications based either on semantic or grammatical features. Matti Kuusi and Outi Lauhakangas have developed an international classification system of proverbs. It consists of 13 main themes: practical knowledge of nature; faith and basic attitudes; basic observations and socio-logic; the world and human life; sense of proportion; concepts of mortality; social life; social interaction; communication; social position; agreements and norms; coping and learning; time and sense of time (Mieder 2004:16-17). Kunin points to certain semantic and grammatical features of proverbs. Speaking about the semantic classification he singles out the main topic groups as well as such components as metaphor, repetition, comparison. Monosemy of proverbs is mentioned as one of their main features. Grammatically he groups proverbs into declarative, interrogative and imperative. In his studies on proverbs, N.R.Norrick also touches upon the grammatical features, especially on the ungrammaticality of proverbs (Sure blind, sure find; fair in the cradle and fair in the saddle, etc.). He points to ellipsis or overextensions to grammatical rules as the reasons for such ungrammaticality (cited by R.Honeck 1997:14).

Stylistic characteristics are also mentioned by various scholars. Kunin mentions the following stylistic peculiarities: repetitions, euphonic features (assonance, alliteration, rhyme). Almost the same stylistic features (alliteration, parallelism, rhyme, hyperbole, 
paradox, personification, metaphor, metonymy, simile, oxymoron) were singled out as constituent parts and indicators of proverb structures by A.Tylor (cited from Mieder 2004:126), R. Honeck 1997:66-83, Sh. Arora and other scholars.

Besides the semantic and grammatical classifications, European linguistics distinguishes the following proverb subgenres: proverbial expressions, proverbial comparisons, proverbial interrogatives, twin formulas. A special subgenre of wellerism*, named after Ch. Dickens's hero Sam Weller ('The Posthumous Papers of the Pickwick $\left.C l u b^{\prime}\right)$, has also found its place in the classification. This subgenre has become a subject of heated discussions since in form and structure wellerisms do not belong to proverbs. Humour is a constituent part of a wellerism, and as Mieder mentions, due to it proverbs tend to acquire sexual or scatological overtones, e.g. "Everyone to his own taste", as the farmer said when he kissed the cow"; "One good turn deserves another", said the customer, as he padded the chorus girls'tights. (Mieder 2004:15-16).

Thus, in conclusion we can state that proverbs, as complex linguistic units, are studied by various branches of linguistics. Up till now there is no common idea concerning proverb definition or their classification. However, scholars agree on the question of cultural peculiarities of proverbs, since being part of the language, they are at the same time part of culture. Proverbs reflect the identity and wisdom of the nation and serve as material for linguistic investigation on different levels.

\section{Notes:}

* Wellerism -is constructed in a triadic manner and consists of a statement (often a proverb), an identification of a speaker (person or animal) and a phrase that places the statement into an unexpected situation. E.g.: "Every evil is followed by some good," as the man said when his wife died the day after he became bankrupt." Taylor and Mieder mention that wellerisms existed long before Dickens, e.g. in Aesop's fables.

\section{References:}

1. Dundes, A. (1994) In the structure of the Proverb // The wisdom of many. Essays on the proverb. / Ed. by Mieder, W.; Dundes, A. Wisconsin: The University of Wisconsin Press.

2. Jamal, M. What is a Proverb? Theoretical Remarks. http://lingua-jip.de

3. Karagiorgos, P. (1999) Greek and English Proverbs. Corfu: Ioannina.

4. Kunin, A.V. (1996) Kurs Frazeologii Angliyskogo Yazyka. Moskva: Vishaya shkola.

5. Kunin, A.V. (1970) Angliyskaya frazeologiya (teoreticeskiy kurs). Moskva: Vishaya shkola.

6. Learning Through Indigenous Proverbs and Myths. http://missiology.org/animism/Learning/proverbs.htm 
7. (1998) Longman Dictionary of English Language and Culture. London: Longman.

8. Mieder, W. (2004) Proverbs. A handbook. Westport, Connecticut: Greenwood Press.

9. (2006) Oxford Advanced Learner's Dictionary. Oxford: Oxford University Press.

10. Richard, P., Honeck (1997) A Proverb in Mind. The Cognitive Science of Proverbial Wit and Wisdom. New Jersey: Lawrence Erlbaum Associates Publishers.

11. Seferyan, S.S. (1992) Imastakhos zhoghovurdy. Angleren-hayeren asacvackner ev patkeravor artahaitutiunner: Yerevan: Areg.

12. The Encyclopedia Britannica. http://www.britannica.com

13. The Columbia Encyclopedia. $6^{\text {th }}$ ed. http://www.bartleby.com/65/pr/proverb.html.

14. Titelman, G. (2000) Random House Dictionary of America's Popular Proverbs and Sayings. $2^{\text {nd }}$ edition. New York: Random House.

15. Wierzbicka, A. (1992) Semantics, Culture and Cognition. Human Concepts in Culture-Specific Configurations. Oxford: Oxford University Press.

16. Zhukov, V. (1966) Slovar' russkikh poslovits i pogovorok. Moskva: Sovetskaya Enciklopediya.

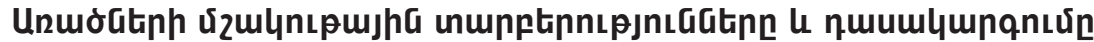

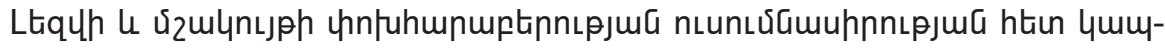

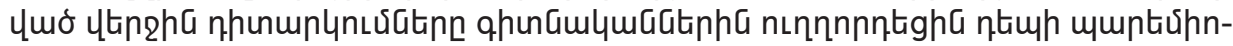

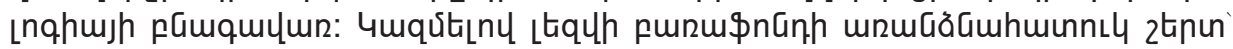

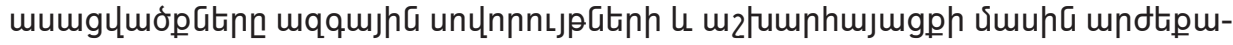

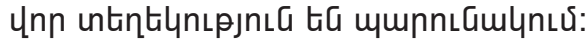

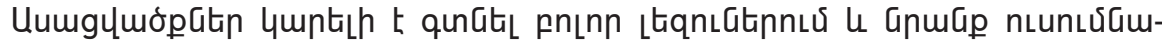

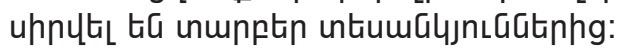

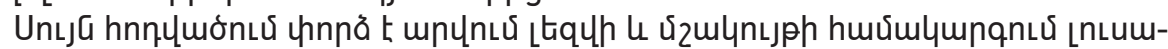

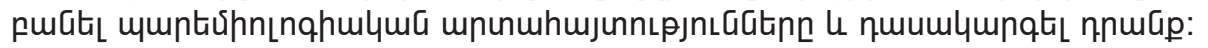

